\title{
Study on Vertical Vibration Characteristics of the 2-DOF Strip Rolling Mill Model with a Single Weak Defect on the Work Roll Bearing Outer Raceway
}

\author{
Zhengnan Sun ${ }^{1}$, Dongxiao Hou ${ }^{{ }^{*}}$, Liang Xu${ }^{1}$, Peiming Shi ${ }^{2}$ \\ ${ }^{1}$ Department of Control Engineering, Northeast University at Qinhuangdao, Qinhuangdao, China \\ ${ }^{2}$ School of Electrical Engineering, Yanshan University, Qinhuangdao, China
}

*Corresponding Author: Dongxiao Hou, Qinhuangdao, Hebei 066004, China; houdongxiao1982@163.com

\begin{abstract}
:
Considering the influence caused by a early single pit defect on the outer raceway of the work roll bearing, a 2-DOF plate strip rolling mill vertical vibration model with a single point weak fault on the outer raceway was established. With the practical parameters of the roughing mill of the 1780 hot continuous rolling mill, the vertical vibration characteristics of the rolling mill work roll with different rotating speed and different single pit defect area on the bearing outer raceway are analyzed by numerical simulation. It is found that with the change of the rotation speed of the work roll, different nonlinear vibration behaviors occurred, such as superharmonic resonance, main resonance, com-bined resonance and sub-harmonic resonance. Especially the subharmonic resonance of the work roll is more harmful than the main resonance when the work roll speed is twice the rotation speed corresponding to the first and second natural frequency of the rolling mill. This work provides a theoretical basis for further clarifying the effect caused by a early defect of the work roll bearing on the mill vibration.

Keywords: Work roll bearing; Weak defect; Strip mill; Vertical vibration

Citation: Z.N. Sun et al, Study on Vertical Vibration Characteristics of the 2-DOF Strip Rolling Mill Model with a Single Weak Defect on the Work Roll Bearing Outer Raceway. Mech Eng Sci, 2019,1(1): 65-70. https://doi.org/10.33142/me.v1i1.664
\end{abstract}

\section{Introduction}

With the increase requirements in rolling speed and product quality, the problem about vibration of the strip mill has become increasingly prominent. The vibration not only affects the surface quality of the rolled product, but the frequent vibration also accelerates the wear of the rolling equipment components, thereby reducing the service life of the rolling equipment. There are many reasons for the vibration of the rolling mill, Wu et al. studied the effects of different sizes defects on the surface of the work roll of the Sendzimir 20-high rolling mill on the vibration characteristics, which provides a theoretical basis for monitoring the indentation defects on the surface of the work roll ${ }^{[1]}$. Lu et al. proposed a dynamic increment model for chatter in a Universal Crown Contral mill(UCM mill), which considering strip hardening, elastic deformation of the work roll, nonlinear friction, transfer delay of the strip and dynamic coupling effect of tension between adjacent stands,and his work provides a more accurate prediction of mill chatter and a basis for optimal design of rolling parameters ${ }^{[2]}$. Shi studied the influence casued by the angle of the jointed shaft in the drivelines of the rolling mill and the friction force of the roll gap on the nonlinear vibration of the rolling mill, and found that the optimal angle of the jointed shaft is $4.7613^{\text {o[3] }}$. Study by Vladimir et al. have shown that the main cause of chatter in the rolling mill is the frictional conditions in the roll gap, and then is the residual chatter marks on the roll, which sometimes can also cause chatter ${ }^{[4]}$.

A work roll bearing defect can also cause the vibration of the rolling mill as a common factor. Son et al. first proposed that the defect of the work roll bearing and the backup roll oil film bearing can cause the vibration of the rolling mill ${ }^{[5]}$. Wu et al. analyzed the vibration power spectrum of the rolling mill by measuring the vibration of the high-speed rolling mill, and found that the frequency modulation is caused by 12 ripples in the inner raceway of the work roll bearing ${ }^{[6]}$. Youngdeuk et al. established a six-degree-of-freedom vibration model of a cold tandem mill considering the stiffness caused by roller bearings and contact between rolls, the chatter frequency affecting the rolling performance was found by studying the dynamic characteristics of the rolling mill vibration ${ }^{[7]}$. Work roll bearings are important rotating parts in the mill work stand, which carries 
a heavy working load and in a poor working environment. Its operating state directly affects the rolling precision of the rolling mill. The rolling mill often vibrates when the work roll bearing has a certain degree of defect. And then the quality of the product is affected. At present, the vibration behavior caused by the failure of the rolling mill work roll bearing, are often measured and diagnosed from the bearing alone, which neglecting the mutual coupling between the work roll bearing and the rolling mill mechanical structure. Therefore, it is impossible to find out the influence rule of the work roll bearing defect on the nonlinear vibration of the rolling mill.

Therefore, this paper established a vertical vibration model of a two-degree-of-freedom strip mill with a single point pit defect on the work roll bearing outer raceway. With the practical parameters of the roughing mill of 1780 hot continuous rolling mill, analyzing the vertical vibration dynamics of the rolling mill under the conditions of different work roll speeds and single pit defect areas on bearing outer raceway, which provides a theoretical basis for further clarifying the effect of a early defect of the work roll bearing on the rolling mill vibration. In actual production of the factory, we can estimate whether the working roll bearing is likely to fail according to its vibration characteristics when the mill vibrates. Replace the defected bearing in time. Finally, the production efficiency of the factory is improved.

\section{The 2-DOF Vertical Vibration Model of the Roll-} ing Mill with a Single Pit Weak Raceway Defect on the Work Roll Bearing

\subsection{Contact Force Model of the Work Roll Bearing with a Sin- gle Pit Weak Raceway Defect}

Considering the bearing outer raceway weak defect, idealized the defect area as a closed ellipse, so the schematic diagram of the weak defect model on the outer raceway of the work roll bearing can be drawn, as shown in Figure 1.

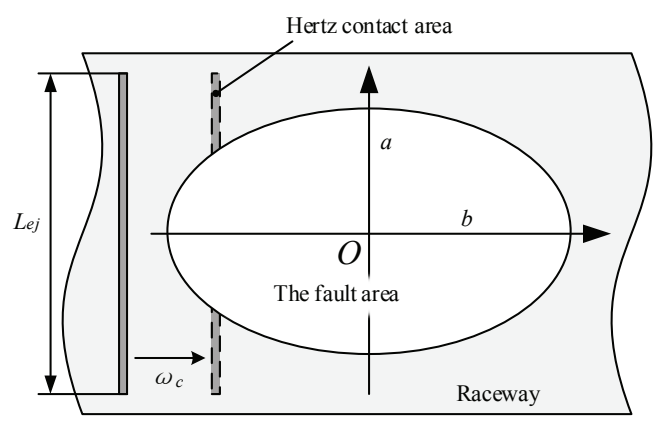

Figure 1. Schematic diagram of weak defect model on the outer raceway

In the Figure $1, L_{e j}$ is the effective contact length between the rolling element $j$ and the outer raceway, $\omega_{c}$ is the rotation angular velocity of the cage, $a$ is the short axis length of the elliptical defect zone, and $b$ is the long axis length of the elliptical defect zone. According to the defect model in Figure 1, the total contact force $F_{b}\left(x_{2}\right)$ between the roller and the raceway is ${ }^{[8]}$

$F_{b}\left(x_{2}\right)=\sum_{j=1}^{Z} K_{j} \delta_{j}(t)^{10 / 9} \cos \alpha \sin \varphi_{j}(t)$
In Equation (1), $Z$ is the number of rollers in the bearing, $\varphi_{j}(t)$ is the position of rolling element $j, \varphi_{j}(t)=2 \pi(j-1) / Z+\omega_{c} t . \omega_{c}$ is the rotation angular velocity of the cage, $\omega_{c}=(n \pi / 60)\left(1-D_{b}\right.$. $\left.\cos \alpha /\left(\left(d_{o}+d_{i}\right) / 2\right)\right), n$ is the run speed of the work roll, $D_{b}$ is the average diameter of the roller cross section, $d_{o}$ and $d_{i}$ are the outer diameter and inner diameter of the bearing, respectively. $K_{j}$ is the total contact stiffness between the inner and outer raceways of the work roll bearing and rolling element $j$.

$k_{j}=8.06 \times 10^{4} L_{e j}^{8 / 9} 2^{9 / 10}$

With $L_{e j}$ is defined as

$L_{e j}=\left\{\begin{array}{l}L_{e}-y, \theta<\frac{\varphi_{d}}{2} \\ L_{e}, \quad \theta \geq \frac{\varphi_{d}}{2}\end{array}\right.$

Where $L_{e}$ is the ideal contact length between the roller and the outer raceway without defect, $\varphi_{d}$ is the angular extent of the outer raceway defect, which is defined as $\varphi_{\mathrm{d}}=4 b / D_{0} . \theta$ is the angular distance between the defect center and Hertz contact line for rolling element $j$ and the outer raceway, $\theta=\left|\bmod \left(\varphi_{j}(t), 2 \pi\right)-1.5 \pi\right|$. $y$ is the length of the roller that is not in effective contact with the raceway in the defect zone, and is defined as

$y=2 a \sqrt{1-\theta^{2} D_{0}^{2} \gamma\left(4 b^{2}\right.}$ face.

Where $D_{0}$ is the average diameter of the outer raceway sur-

The contact deformation $\delta_{j}(t)$ for rolling element $j$ between the inner and outer raceway is given by

$$
\delta_{j}(t)=x_{0} \sin \varphi_{j}(t) \cos \alpha+x_{2} \cos \varphi_{j}(t) \cos \alpha+z_{0} \sin \alpha
$$

Where $x_{0}, x_{2}$ and $z_{0}$ is the relative displacement of the inner and outer raceway in the horizontal direction, the vertical direction and the axial direction, respectively.

2.2. 2-DOF Vertical Vibration Model of the Rolling Mill with a Weak Defect on the Work Roll Bearing Outer Raceway

Considering the influence of the contact force of the work roll bearing with defect in Equation (1), a 2-DOF vertical vibration model of the rolling mill with a weak defect of the work roll bearing can be established, as shown in Figure 2.

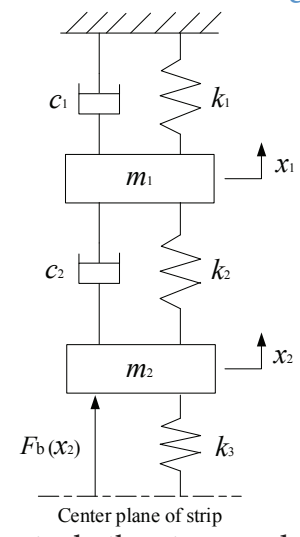

Figure 2.2-DOF vertical vibration model of the rolling mill with a weak defect on the work roll bearing 
The model includes a equivalent mass $m_{1}$ representing the upper backup roll, its bearing and bearing seat. a equivalent mass $m_{2}$ representing the upper work roll, its bearing and bearing seat. The spring and damper constants $k_{1}$ and $c_{1}$ represent the stiffness and damping between the upper backup roll and the middle part of mill beam. The spring and damper represent the spring and damper constants $k_{2}$ and $c_{2}$ represent the stiffness and damping between the upper backup roll and the upper work roll. The spring costant $k_{3}$ represents the stiffness between the work roll and the strip. The force $F_{b}\left(x_{2}\right)$ represents the faulty reaction force of the work roll bearing to the work roll.

Using the rolling mill vertical vibration model in Figure 1, the equations of the dynamic motion are now given by

$$
\begin{aligned}
& m_{1} \ddot{x}_{1}+c_{1} \dot{x}_{1}+c_{2}\left(\dot{x}_{1}-\dot{x}_{2}\right)+k_{1} x_{1}+k_{2}\left(x_{1}-x_{2}\right)=0 \\
& m_{2} \ddot{x}_{2}+c_{2}\left(\dot{x}_{2}-\dot{x}_{1}\right)+k_{2}\left(x_{2}-x_{1}\right)+k_{3} x_{2}=F_{b}\left(x_{2}\right)
\end{aligned}
$$

\section{Simulation and Analysis}

Using the actual parameters of the rough rolling mill of the 1780 hot strip mill in a factory ${ }^{[9]}$, the mechanical parameters of the rolling mill are shown in Table 1.

Table 1. Mechanical structure parameters of the roughing mill of the 1780 hot strip mill

\begin{tabular}{ccc}
\hline Variable & Unit & Value \\
\hline$m_{1}$ & $k g$ & $7.59 \times 10^{4}$ \\
$m_{2}$ & $k g$ & $1.596 \times 10^{4}$ \\
$k_{1}$ & $\mathrm{~N} / \mathrm{m}$ & $3.241 \times 10^{10}$ \\
$k_{2}$ & $\mathrm{~N} / \mathrm{m}$ & $5.948 \times 10^{10}$ \\
$k_{3}$ & $\mathrm{~N} / \mathrm{m}$ & $2.566 \times 10^{10}$ \\
$c_{1}$ & $\mathrm{~N} \cdot \mathrm{s} / \mathrm{m}$ & $3 \times 10^{6}$ \\
$c_{2}$ & $\mathrm{~N} \cdot \mathrm{s} / \mathrm{m}$ & $5 \times 10^{5}$
\end{tabular}

The structural size parameters of the work roll bearing are shown in Table 2.

Table 2. Parameter values of the rolling mill bearing

\begin{tabular}{ccc}
\hline Description & Variable/Unit & Value \\
\hline $\begin{array}{c}\text { Outer diameter } \\
\text { Inner diameter }\end{array}$ & $d_{0} / m m$ & 900 \\
$d_{i} / m m$ & 710 \\
$\begin{array}{c}\text { vverage diameter of the } \\
\text { outer raceway surface }\end{array}$ & $D_{0} / m m$ & 845 \\
$\begin{array}{c}\text { Average diameter of the } \\
\text { roller cross section }\end{array}$ & $D_{b} / m m$ & 49.8 \\
Roller effective length & $L_{e} / m m$ & 53.64 \\
Number of rollers & $Z$ & 32 \\
Contact angle & $\alpha$ & $13^{\circ} 8^{\prime} 21^{\prime \prime}$ \\
\hline
\end{tabular}

3.1. Calculation of a Single Pit Defect Frequency on Bearing Outer Raceway

The frequency of the bearing rolling element passing through a point on the outer ring raceway is calculated as ${ }^{[10]}$

$f_{o}=\frac{Z n}{120}\left(1-\frac{D_{0}}{d_{m}} \cos \alpha\right)$

The first and second natural frequencies of the two-degree- of-freedom rolling mill vertical vibration model can be calculated from Equation (6) as follows

$$
\left\{\begin{array}{l}
f_{1}=122.84 \mathrm{~Hz} \\
f_{2}=391.19 \mathrm{~Hz}
\end{array}\right.
$$

\subsection{Analysis of Vibration Characteristics of the Work Roll} with a Single Pit Defect on Bearing Outer Raceway

Figure 3-5 present the frequency spectrum waterfall figures of the vertical vibration displacement of the work roll with the change of the work roll rotation speed, when the defect area $S$ of the work roll bearing outer raceway is $8.75 \pi \mathrm{mm}^{2}, 35 \pi \mathrm{mm}^{2}$ and $140 \pi \mathrm{mm}^{2}$ respectively.

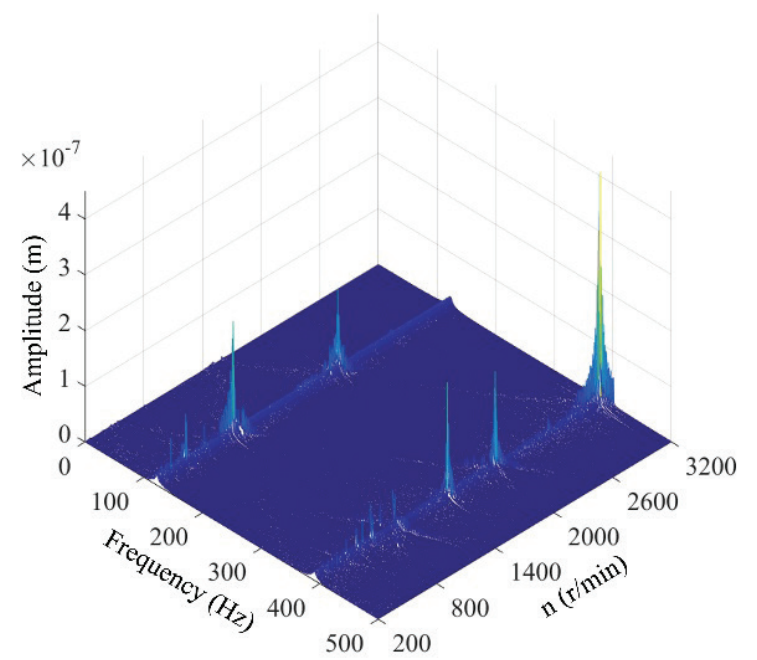

Figure 3. The frequency spectrum waterfall of the vibration displacement of the work roll with the change of the work roll rotation speed $\left(S=8.75 \pi \mathrm{mm}^{2}\right)$

Figure 3 presents that the work roll exhibits different spectrum characteristics with different speeds, when the rotation speed reaches $490 \mathrm{r} / \mathrm{min}$ (the rotation speed corresponding to the first natural frequency), its spectrum curve shows a distinct peak at $123 \mathrm{~Hz}$, at this point, the rolling mill has resonance at the first natural frequency. When the rotation speed reaches $980 \mathrm{r} / \mathrm{min}$ (twice the speed corresponding to the first natural frequency), the resonance of the first natural frequency in the work roll will become more intense, the sub-harmonic resonance occurred in the rolling mill at this time, we can see that the subharmonic resonance has a greater influence than the main resonance according to this phenomenon. Therefore, except the work roll rotation speed corresponding to the first natural frequency, it is necessary to avoid twice the rotation speed of the work roll corresponding to the first natural frequency. When the rotation speed reaches $1561 \mathrm{r} / \mathrm{min}$, the work roll exhibits a main resonance of the second natural frequency. When the rotational speed reaches 2051 $\mathrm{r} / \mathrm{min}$, resonance of the first and the second natural frequency occurs at the same time, and this behavior also called the combined resonance. When the rotation speed reaches $3122 \mathrm{r} / \mathrm{min}$ (twice the rotation speed corresponding to the second natural frequency), the sub-harmonic resonance of the second natural frequency appears again on the work roll.

Figure 3-5 present that sub-harmonic resonance of the second natural frequency will be weakened as the defect area increases, but the main resonance is enhanced when the defect frequency is consistent with the first and second natural fre- 
quencies, respectively. Among the vibration behaviors caused by the work roll rotation speed from $200 \mathrm{r} / \mathrm{min}$ to $3200 \mathrm{r} / \mathrm{min}$, when the defect frequency is twice the work roll speed corresponding to the first and second natural frequencies, the induced subharmonic resonance is the most serious, respectively. In particular, the subharmonic resonance caused by the defect frequency being twice the second natural frequency of the rolling mill is the most serious.

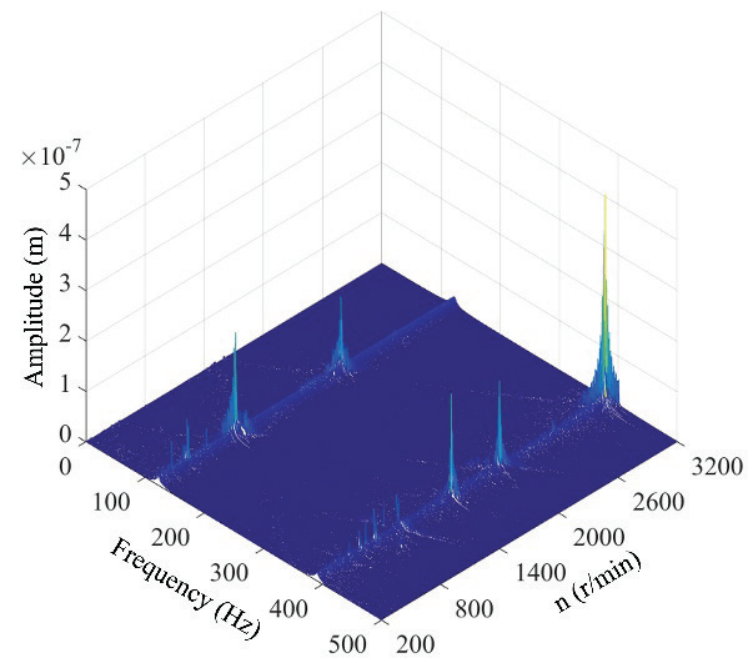

Figure 4. The frequency spectrum waterfall of the vibration displacement of the work roll with the change of the work roll rotation speed $\left(S=35 \pi \mathrm{mm}^{2}\right)$

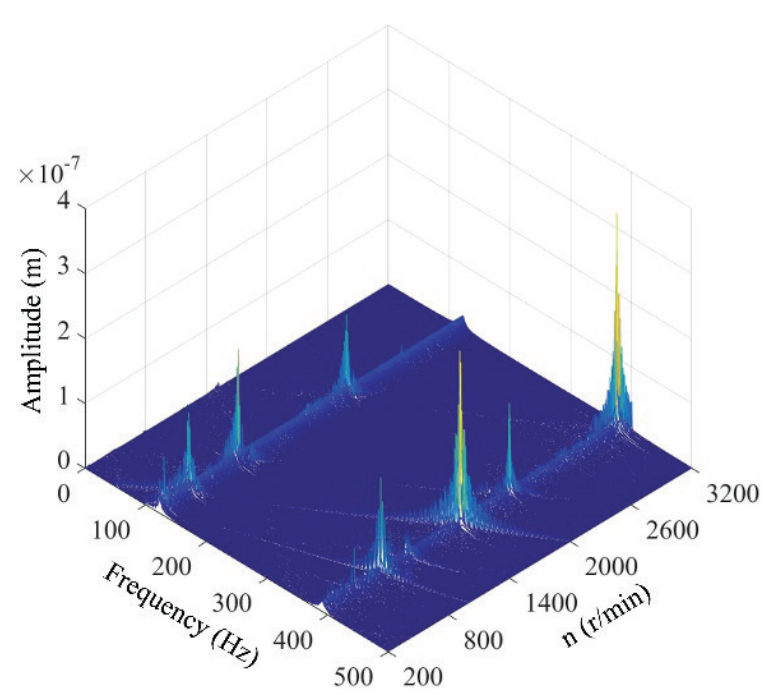

Figure 5. The frequency spectrum waterfall of the vibration displacement of the work roll with the change of the work roll rotation speed $\left(\mathrm{S}=140 \pi \mathrm{mm}^{2}\right)$

Figure 6 presents the vibration displacement of the work roll under the working conditions of the work roll bearing without defect and micro-defect (the bearing outer raceway defect area is $8.75 \pi \mathrm{mm}^{2}$ ) when the work roll rotation is $200 \mathrm{r} / \mathrm{min}$ (no resonance). The partial enlargement in the figure is the comparison curve when the vibration reaches steady state. It can be seen that when there is a defect, the work roll exhibits a vibration behavior; however, as the defect is weak, the vibration amplitude of the work roll is very small (the amplitude fluctuation is about $\left.2.2 \times 10^{-8} \mathrm{~m}\right)$.

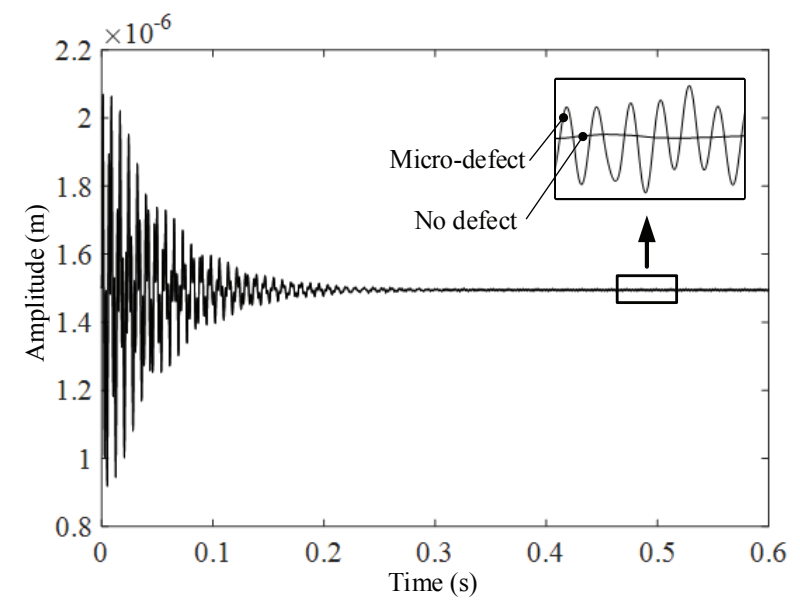

Figure 6. Work roll vibration displacement with or without micro-defect

In the Figure 6, the speed of the working roller is $200 \mathrm{r} /$ min (the defect frequency is $50.12 \mathrm{~Hz}$ at this speed), the single pit weak defect area $S$ of the work roll bearing is $35 \pi \mathrm{mm}^{2}$, there is the displacement time domain curve of the work roll vibration and its corresponding spectrum analysis curve.

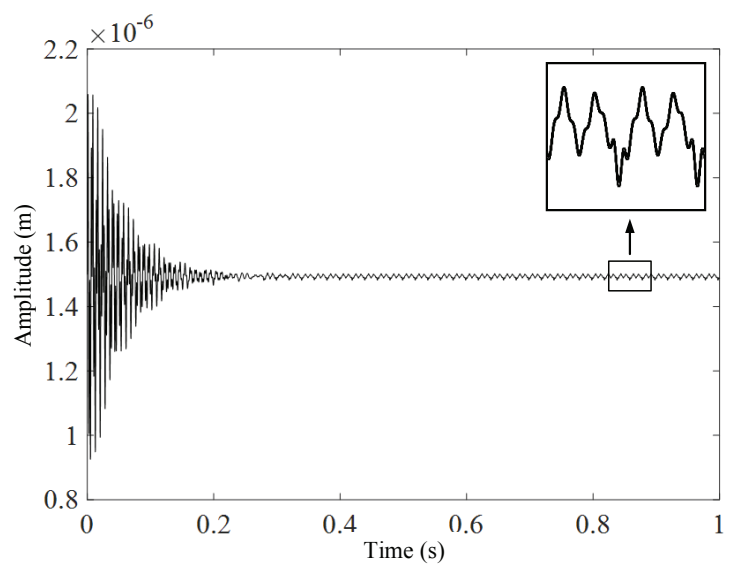

(a) Displacement of the work roll

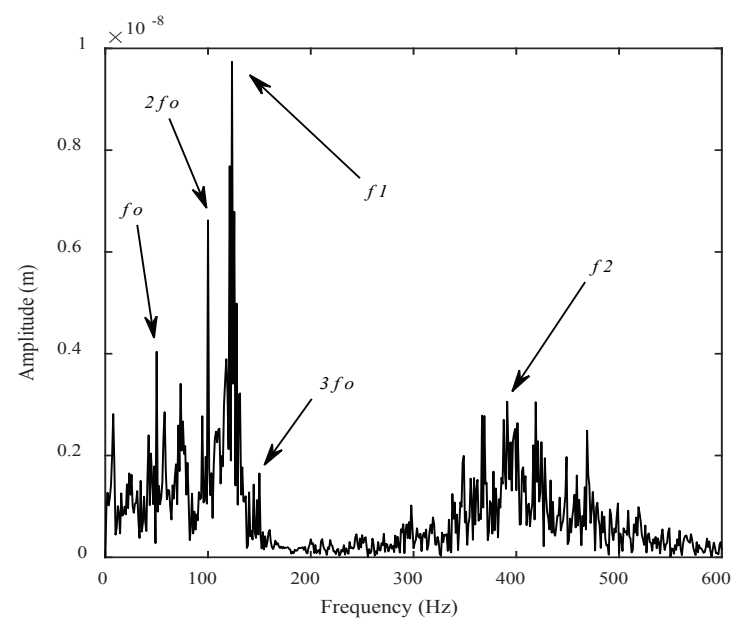

(b) Spectrum analysis of the work roll

Figure 7. Vibration displacement and spectrum of the work $\operatorname{roll}\left(n=200 \mathrm{r} / \mathrm{min}, \quad S=35 \pi \mathrm{mm}^{2}\right)$ 
In the Figure 7(a), the rolling mill presents complex periodic vibrations at this point. Also, we can see that the vibration frequency component of the work roll is very complicated at this time. In addition, except the defect frequency $f_{o}$, the natural frequencies $f_{1}$ and $f_{2}$, other frequency components appear, such as $2 f_{o}$ and $3 f_{o}$.

In the Figure 8, the speed of the work roll is $490.17 \mathrm{r} / \mathrm{min}$ (the speed corresponding to the second natural frequency), the single pit weak defect area $S$ of the work roll bearing is $35 \pi \mathrm{mm}^{2}$, there is the displacement time domain curve of the work roll vibration and its corresponding spectral analysis curve.

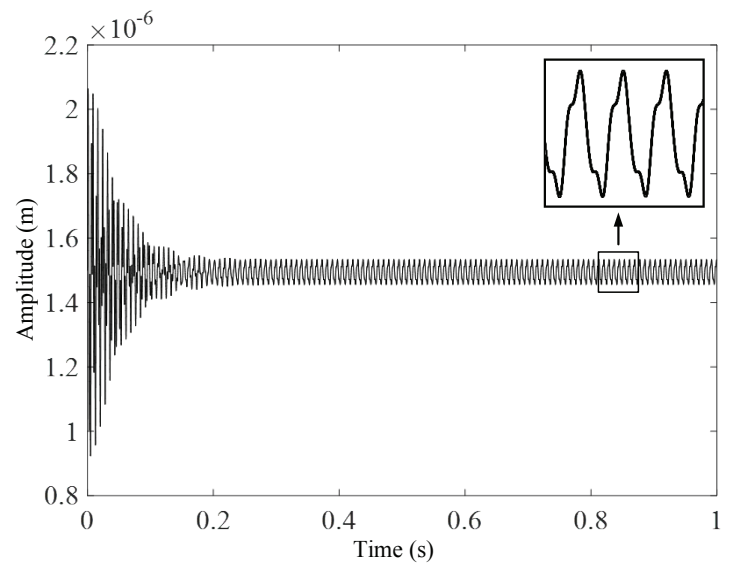

(a) Displacement of the work roll

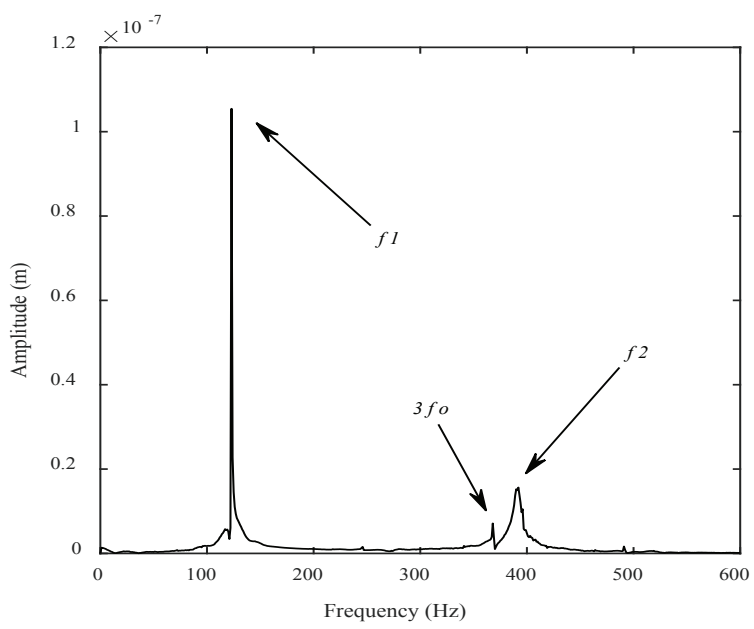

(b) Spectrum analysis of the work roll

Figure 8. Vibration displacement and spectrum of the work $\operatorname{roll}\left(n=490.17 \mathrm{r} / \mathrm{min}, S=35 \pi \mathrm{mm}^{2}\right)$

In Figure 8(b), we can see that except the first and second natural frequency components of the work roll vibration frequencies, there is also a triple frequency component of the first frequency, and the first natural frequency has the largest amplitude among the frequency components.

In Figure 9, the speed of the work roll is $1561 \mathrm{r} / \mathrm{min}$ (The speed corresponding to the second natural frequency), the single pit weak defect area $S$ of the work roll bearing is $35 \pi \mathrm{mm}^{2}$, there is the displacement time domain curve of the work roll vibration and its corresponding spectral analysis curve

In Figure 9(b), we can see that the vibration frequency components of the work roll contain the first and second natural fre- quency components, and the second natural frequency has the largest vibration amplitude.

\section{Conclusion}

(1) Considering the early single pit weak defect on the outer raceway of the work roll bearing, the vertical vibration model of a 2-DOF strip mill with a weak defect of the work roll bearing is established.

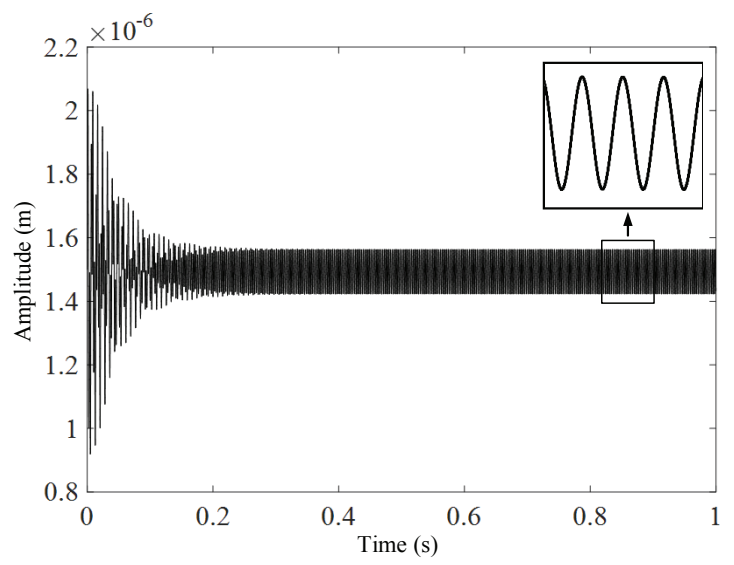

(a) Displacement of the work roll

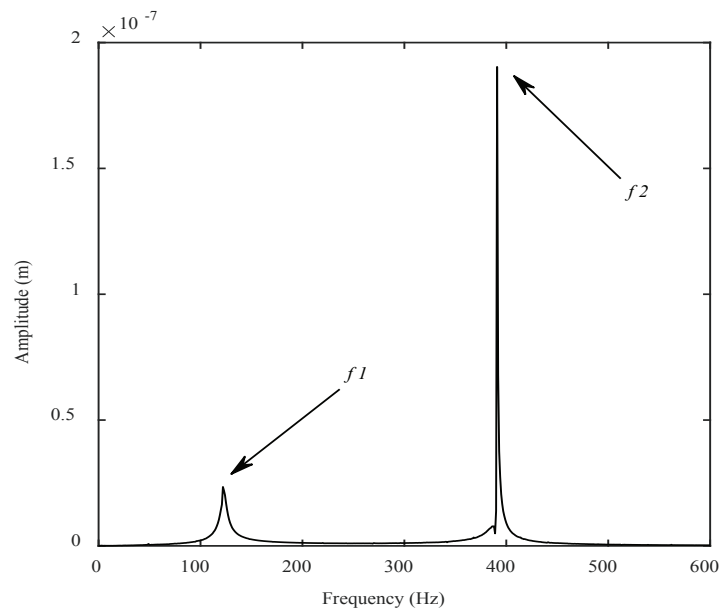

(b) Spectrum analysis of the work roll

Figure 9. Vibration displacement and spectrum of the work $\operatorname{roll}\left(n=1516 \mathrm{r} / \mathrm{min}, S=35 \pi \mathrm{mm}^{2}\right)$

(2) When a single pit weak defect presents on the outer raceway of the work roll bearing, the work roll exhibits nonlinear vibration behaviors such as main resonance, superharmonic resonance, subharmonic resonance, and combined resonance. As the defect area $S$ is $35 \pi \mathrm{mm}^{2}$ (the defect is weak), the subharmonic resonance becomes the most severe. As the defect area increases gradually, the subharmonic resonance weakens and the main resonance increases.

(3) The research work of this paper has important reference significance for the simulation of rolling mill vibration with defect on the work roll bearing practically and further clarifying the vibration mechanism of the rolling mill caused by the defect on the outer raceway of the work roll bearing.

Author Contributions: This article presented in the paper was completed by Sun in theoretical derivation and simulation. Hou 
proposed the idea of the article. Xu and Shi assisted Sun in completing the simulation.

Conflict of Interest: No conflict of interest was reported by the authors.

Acknowledgments: This research is supported by Natural Science Foundation of China (Grant no. 51405068), Natural Science Foundation of Hebei Province of China (Grant no.E2019203146), and Natural Science Foundation of Hebei Province of China (Grant no.E2014501006).

\section{References}

[1]. Shengli Wu, Liming, Yinmin Shao, et al. Vibration characteristic analysis of twenty-high rolling mill with local defect on roll surface based on the time-varying contact stiffness. Engineering Failure Analysis 2014; 42: 297-310.

[2]. Xing Lu, Jie Sun, et al. Dynamic analysis of vibration stability in tandem cold rolling mill. Journal of Materials Processing Technology 2019; 272:47-57.

[3]. Pei-ming SHI, Ji-zhao LI, et al. Nonlinear Dynamics of Torsional Vibration for Rolling Mill's Main Drive System Under Parametric Excitation. Journal of Iron and Steel Rsearch, International 2010; 20: 7-12.

[4]. Vladimir Panjkovic, Ronald Gloss, John Steward, et al.
Causes of chatter in a hot strip mill: Observations, qualitative analyses and mathematical modelling. Journal of Materials Processing Technology 2012; 212(4): 954-961.

[5]. Son, B., Roh, Y., and Lee, Y., "The Cause of Vibration at Finishing Stands in a Hot Strip Mill," Korean Society for Noise and Vibration Engineering 1994; 1(4), 43-50,

[6]. Wu, Y. X. and Duan, J. A., Frequency modulation of highspeed mill chatter, J. Mater. Process. Technol. 2002; 129: $148-151$.

[7]. Youngdeuk Kim, Chang-Wan Kim, Sungjin Lee, and Hyunchul Park. Dynamic Modeling and Numerical Analysis of a Cold Rolling Mill. International Journal of Precision Engineering and Manufacturing 2013; 14(3): 407-413.

[8]. Xiang LI, Li-yan HAN, Yong-sheng ZHU, et al. Fault diagnosis based on nonlinear dynamic modeling in tapered roller bearing. Journal of Vibration and Shock 2014; 33(S):128131.

[9]. Jing Zhao. Vibration analysis of 1780 HSM R1 machine. Qinhuangdao: Yanshan University, 2011.

[10]. Dick Petersen, Carl Howard, Nader Sawalhi, et al. Analysis of bearing stiffness variations, contact forces and vibrations in radially loaded double row rolling element bearings with raceway defects. Mechanical Systems and Signal Processing 2015; 50-51: 139-160. 